\title{
The Structure of Cool Flame Fronts of Pentane, Iso-Pentane and Their Mixture
}

Z.A. Mansurov, A.A. Mironenko, D.U. Bodykov, K.N. Rahkimetkaliev, C.K. Westbrook

This article was submitted to

Twenty Eighth International Symposium on Combustion, Edinburgh, Scotland, July 30 - August 4, 2000

January 11, 2000 


\section{DISCLAIMER}

This document was prepared as an account of work sponsored by an agency of the United States Government. Neither the United States Government nor the University of California nor any of their employees, makes any warranty, express or implied, or assumes any legal liability or responsibility for the accuracy, completeness, or usefulness of any information, apparatus, product, or process disclosed, or represents that its use would not infringe privately owned rights. Reference herein to any specific commercial product, process, or service by trade name, trademark, manufacturer, or otherwise, does not necessarily constitute or imply its endorsement, recommendation, or favoring by the United States Government or the University of California. The views and opinions of authors expressed herein do not necessarily state or reflect those of the United States Government or the University of California, and shall not be used for advertising or product endorsement purposes.

This is a preprint of a paper intended for publication in a journal or proceedings. Since changes may be made before publication, this preprint is made available with the understanding that it will not be cited or reproduced without the permission of the author.

This report has been reproduced directly from the best available copy.

Available electronically at http://www.doe.gov/bridge

Available for a processing fee to U.S. Department of Energy and its contractors in paper from

U.S. Department of Energy

Office of Scientific and Technical Information

P.O. Box 62

Oak Ridge, TN 37831-0062

Telephone: (865) 576-8401

Facsimile: (865) 576-5728

E-mail: reports@adonis.osti.gov

Available for the sale to the public from

U.S. Department of Commerce

National Technical Information Service

5285 Port Royal Road

Springfield, VA 22161

Telephone: (800) 553-6847

Facsimile: (703) 605-6900

E-mail: orders@ntis.fedworld.gov

Online ordering: $\underline{\text { http://www.ntis.gov/ordering.htm }}$

\section{OR}

Lawrence Livermore National Laboratory

Technical Information Department's Digital Library

http://www.llnl.gov/tid/Library.html 
The Structure of Cool Flame fronts of pentane, iso-pentane and their mixture.

\author{
Z.A.Mansurov ${ }^{1}$, A.A.Mironenko ${ }^{1}$, D.U.Bodykov ${ }^{1}$, K.N.Rakhimetkaliev ${ }^{1}$, \\ Ch.K.Westbrook ${ }^{2}$. \\ 'Al-Farabi Kazakh State National University \\ ${ }^{2}$ University of California Lawrence Livermore National Laboratory
}

Submitted to the Twenty Eighth International Symposium on Combustion University of Edinburgh

Scotland

30-th July to 4-th August 2000

Subject: Laminar Flames

Address correspondence concerning this manuscript to Prof. Zulkhair

A.Mansurov

Kazakh State National University

Karasai Batyr str., 95

Almaty, 480012, Kazakhstan

Phone: (3272) 636297

Fax: (3272) 472609

E-mail: mansurov@chem.iatp.kz

Word Count

Text: $\quad 2740 \quad$ Microsoft word count

11 Figures: 2200

2 standard tables $\quad 400$

Total

5340 


\begin{abstract}
An experimental study of the combustion of two isomers of pentane, n-pentane and isopentane, in laminar cool flames has been carried out. Three flames were studied, one with $\mathrm{n}$ pentane, the second with iso-pentane, and the third with an equimolar mixture of the two isomers. Particular attention has been given to the low temperature region ahead of the hot region of the flame and the cool flame chemistry occurring there. Aunique experimental facility has been used to provide access to this cool flame region. Comparisons are made of the structures of the three flames, with particular attention on the different intermediate species produced and the correlations between the fuel molecule structure and the specific intermediates produced.
\end{abstract}




\section{INTRODUCTION}

Investigations of flame structure of stabilized cool flames are important to understand the processes of fuel conversion in both cool and hot flames [1,2]. According to current understanding, the cool flame is considered to be a precursor of the hot flame, so processes occurring in the cool flame should affect the structure of subsequent hot flame. Cool flames produce a negative temperature coefficient in the rate of hydrocarbon oxidation in the low temperature region of the flame front and also influence the heat release in propane, butane and hexane flames [3-5]. Investigations of cool flame structure may throw light on the nature of knock in an internal motor engine and oscillatory phenomena in hydrocarbon flames $[6,7]$.

Low temperature hydrocarbon oxidation depends quite sensitively on the fuel molecular structure and has been demonstrated to be a significant factor in determining the octane and cetane ratings for these fuels. In the present study, low temperature kinetics of isomers of pentane were studied, to provide insight into the role that molecular structure plays in low temperature oxidation rates.

\section{EXPERIMENTAL DETAILS}

We have modified the reactor [3-5] developed by A.A. Mantashyan [8] to study the flame front structure of stabilized cool flames. It is a pyrex reactor consisting of two sections both $62 \mathrm{~mm}$ in diameter, which are heated separately. The length of the first section $L_{1}$ is 300 $\mathrm{mm}$, and that of the second $\mathrm{L}_{2}$ is $100 \mathrm{~mm}$. These sections are separated by a wire-gauze plate of pyrex. This plate has 50 holes with a total area of $50 \mathrm{~mm}^{2}$. The reactor is arranged vertically so that a fuel mixture is supplied into the first section from the bottom. The reactor 
is thermostated by the flow of hot air. The reactor temperature is controlled to an accuracy of $\pm 2{ }^{\circ} \mathrm{C}$ with a temperature controller BT-1. The section temperature is controlled with chromel-alumel thermocouples placed in the thermostat. Temperatures were recorded with control devices KVP-1, KSP-4. The flame process and sonde position were observed through a window. The positions of the sampling sonde and thermocouple sonde relative to the flame over the burner surface were determined with a cathetometer.

Pentane-air cool flames were studied with an installation shown schematically in Fig.1. The special feature of this installation was a specially designed system for preparing and supplying pentane-air mixture of defined preliminary composition into the first section of reactor. This system consists of an inert gas cylinder (2), a powerful pneumatic referenceinput element P2_D.4 (6), a manometer (3), a five litre vessel of stainless steel ( 4 ), a calibrated capillary (17) and a mixer (8). Pentane is added to the vessel where inert gas is fed through a manotube (15), and the gauge pressure over the liquid is set with the reference-input element. Under pressure, pentane runs through a capillary into the mixer. It should be noted that both the vessel with pentane and capillary are thermostated at the temperature of $285 \mathrm{~K}$. The vessel pressure is controlled with the manometer (3). The mixer consists of two chambers (I,II) connected with a cross-pipe tube. Pentane goes to chamber I from the capillary, then it evaporates and enters the first section of chamber II through the cross-pipe tube. Air is pumped into the system with a compressor (5) through a reservoir (16), cleaning filters, a fine adjustment valve (1) and a flow meter (7). Air with a predetermined flow rate goes through a coil pipe where it is heated and then comes to the mixer through a small nozzle, then air is combined with pentane vapor and the air and pentane are mixed in the second 
section of the chamber II. After that the vapour-gas mixture goes through another coil-pipe into a heat exchanger (III) having the same temperature as in the mixer and enters the first section of the reactor. The mixer and coil pipe are made of molybdenum glass, and they are submerged into the ultrathermostat U-2 where the temperature of $345 \pm 0.1 \mathrm{~K}$ is kept constant. A tap for controlling the composition of the initial mixture supplied into the reactor is placed between the mixer and heat exchanger.

Temperature profiles of pentane-air cool flames were taken along an axis of the reactor second section with a thermocouple which was not isolated. The working part of the thermocouple was covered with diethyl ether of orthosilicon acid [9]. In the investigation of pentane-air flames, temperature profiles both of the flame and inert gas (air) were taken. The air flow rate was set as high as the total flow rate of pentane-air mixture at temperatures of both sections corresponding to the performed experiment.

Analysis of the reaction products was carried out using two $M=3700$ chromatograph devices. Helium of high purity was used as a gas carrier. The investigation was conducted with a heat conduction detector. The detector signal was recorded with an electron potentiometer. Flow rate of the gas carrier was $41 \mathrm{~cm}^{3} / \mathrm{min}$. During the chromatographic analysis the temperature of the thermostat columns was controlled with programming $\left(40^{\circ} \mathrm{C}-2 \mathrm{~min}-3^{\circ} \mathrm{C} / \mathrm{min}-83^{\circ} \mathrm{C}-6 \mathrm{~min}-200^{\circ} \mathrm{C}-20 \mathrm{~min}\right)$. Metallic columns with inner diameter of $2 \mathrm{~mm}$ and length of $2 \mathrm{~m}$ were used. This programming control was chosen on the base of a great number of experiments which enabled us to use effectively available sorbents. Due to the different polarity of the sorbents we had to identifiy qualitatively the components of the analysed mixture. 
For the computation of product composition the method of internal identification involving mole correction factors taken from reference [10] was used. The computation used the formula:

$$
C_{i}=\frac{K_{i} Q_{i}}{\sum K_{i} Q_{i}} \times 100
$$

where the $K_{i}$ - coefficient was defined by detector sensivity to the current component, $Q_{i}$ - square of the i-th peak, $C_{i}$ - the i-th compound concentration in volume percents.

For calibration we used the following substances:

$\mathrm{CH}_{4} \mathrm{CO}, \mathrm{CO}_{2}, \mathrm{CH}_{2} \mathrm{O}, \mathrm{CH}_{3} \mathrm{CHO}, \mathrm{C}_{4} \mathrm{H}_{10}, \mathrm{H}_{2} \mathrm{O}, \mathrm{C}_{3} \mathrm{H}_{6}, \mathrm{C}_{3} \mathrm{H}_{6} \mathrm{O}, \mathrm{C}_{3} \mathrm{H}_{8}, \mathrm{C}_{4} \mathrm{H}_{8}$, $\mathrm{C}_{5} \mathrm{H}_{10}, \mathrm{C}_{5} \mathrm{H}_{12}, \mathrm{C}_{2} \mathrm{H}_{5} \mathrm{OH}, \mathrm{CH}_{3} \mathrm{OH}, \mathrm{CH}_{3} \mathrm{COOH}, \mathrm{C}_{6} \mathrm{H}_{14}, \mathrm{C}_{6} \mathrm{H}_{6}, \mathrm{C}_{2} \mathrm{H}_{2}, \mathrm{C}_{3} \mathrm{H}_{7} \mathrm{OH}$, $\mathrm{C}_{5} \mathrm{H}_{11} \mathrm{OH},\left(\mathrm{C}_{2} \mathrm{H}_{5}\right)_{2} \mathrm{O}, \mathrm{CH}_{3} \mathrm{CO}_{2} \mathrm{C}_{2} \mathrm{H}_{5}, \mathrm{CH}_{2} \mathrm{OH}-\mathrm{CH}_{2} \mathrm{OH},\left(\mathrm{CH}_{3}\right)_{2} \mathrm{O}$, iso $-\mathrm{C}_{4} \mathrm{H}_{9} \mathrm{OH},\left(\mathrm{CH}_{3}\right)_{2} \mathrm{CO},\left(\mathrm{CH}_{3}\right)_{2} \mathrm{CO}, \mathrm{C}_{2} \mathrm{H}_{5},\left(\mathrm{C}_{3} \mathrm{H}_{5}\right)_{2} \mathrm{O},\left(\text { iso }-\mathrm{C}_{3} \mathrm{H}_{5}\right)_{2} \mathrm{O}$, etc.

As known [10], the time of component yield, and in programming control the yield temperature somewhat differ for individual substances and their mixtures. In particular, in the case of mixtures there is some increasing of these characteristics. That is why for a better identification of the compounds analysed we composed model mixtures which are both gaseous and liquid; and then on the basis of their analysis final conclusions on times and temperature of the component yield as well as their qualitative composition were drawn.

For calibration, all liquid model mixtures were injected with a microinjector directly into the chromatograph evaporator, while gaseous model mixtures were injected here with a dozator. Samples of the reaction products taken were introduced into the chromatograph with 
a six-way cock dozator thermostated at temperature of $120 \pm 0.5^{\circ} \mathrm{C}$. Before each sample was introduced from a new point along the reactor axis, the cock-dozator line and its loop were washed three times with solvent (pentane:ethanol:acetone $=1: 1: 1$ ), to remove the influence of previous sample residuals on the composition of the next sample analysed.

It should be noted that initially the samples were taken through a microcolumn which was cooled with liquid nitrogen and filled with the sorbent identical to that in the chromatographic column. Subsequently the microcolumn was heated up to a temperature of nearly $200{ }^{\circ} \mathrm{C}$. However, a range of experiments has shown that although the microcolumn was heated and washed with sorbents, heavy impurities accumulated on the sorbent, which then sharply reduce the quality of the obtained chromatogrammes and complicate the composition computations and the component identification in the analyzed mixture and, finally, adversely impact data reproducability. Therefore we worked on finding the best conditions for taking samples of composition by cooling the cock-dozator microcolumn with liquid nitrogen. As a result, we chose the heated cock-dozator with a loop which is not filled with sorbent. This cock-dozator is located close to the sampling installation. Samples were taken from the sonde to the cock-dozator through a teflon pipe-line of $2 \mathrm{~mm}$ diameter and $18-20 \mathrm{~cm}$ in the length and introduced into the chromatograph under the vacuum of $180-200$ water column $\mathrm{mm}$. The probe sampling was carried out along the second reactor section axis. A quartz tube with a diameter of $6 \mathrm{~mm}$ and inlet diameter of $50 \mathrm{~mm}$ was used as a sonde. Samples of vapour and gaseous mixture were supplied directly into the heated six-way cock-dozator and then into the chromatograph. 


\section{RESULTS AND DISCUSSION}

In Table 1 the experimental conditions are summarized for the 3 flames which were investigated.

Table 1 .

\begin{tabular}{|l|l|l|l|}
\hline $\begin{array}{l}\text { Conditions of } \\
\text { experiments }\end{array}$ & Pentane-air mixture & Iso-pentane-air mixture & $\begin{array}{l}\text { Pentane- } \\
\text { iso-pentane-air mixture }\end{array}$ \\
\hline $\mathrm{T}_{1}, \mathrm{~K}$ & 373 & 373 & 363 \\
$\mathrm{~T}_{2}, \mathrm{~K}$ & 593 & 578 & 583 \\
Component ratio & 4,85 & 4,75 & 4,17 \\
$\mathrm{Q}_{-} \mathrm{m}^{3 / \mathrm{min}}$ & 320 & 715 & 619 \\
\hline
\end{tabular}

As noted above, the focus of our investigation was the cool flame stabilized at the

following conditions: $\mathrm{T}_{1}=100{ }^{\circ} \mathrm{C}, \mathrm{T}_{2}=320^{\circ} \mathrm{C}$, component ratio was $\mathrm{nC}_{5} \mathrm{H}_{12}$ : air $=4.85$ and the mixture flow rate was $320 \mathrm{~cm}^{3} / \mathrm{min}$. The flame was sonded within the flame region at an interval of $2 \mathrm{~mm}$ from the matrix to flame, and after the flame region the interval was $5 \mathrm{~mm}$. According to this sonding and visual observations the flame location was found. The flame was stabilized at a distance of $4.8 \mathrm{~cm}$ from the matrix. The thickness of the visible flame front was 10-12 mm (Fig 2).

Fig 2 represents two temperature profiles of stabilized cool flame and two-stage flames of pentane. The two stage flame was stabilized at $\mathrm{T}_{1}=110^{\circ} \mathrm{C}, \mathrm{T}_{2}=360^{\circ} \mathrm{C}$ and ratio of $\mathrm{C}_{5} \mathrm{H}_{12}$ : air $=3.5, Q=355 \mathrm{~cm}^{3} / \mathrm{min}$. As shown from Fig 2. at increasing concentration of air the single stage cool flame transitions to two stages (first cool flame and second blue) flame. 
The chromatographic analysis of samples taken along the axis of the first reactor section up to the matrix separating both reactor sections shows that in the first section, major components of the initial mixture were not appreciably consumed.

Among the products of cool flame oxidation of pentane, we have identified the following substances such as nitrogen, oxygen, hydrogen, carbon oxide, carbon dioxide, ethane, propane, propylene, water, formaldehyde, methyl alcohol, acetaldehyde, ethanol, acetone, traces of formic acid, di-isopropyl ether, propyl ether, pentanol, pentene, methylketone, ethylacetate, pentane. Two other peaks and several trace components have not been identified.

One of the major goals of this work was to compare the flame structures of two isomers of pentane. The cool flame temperatures of n-pentane and iso-pentane (2-methyl butane) are compared in Figure 3, and species concentrations for the two fuels are discussed below.

Concentration profiles for the substances identified along the second section axis are presented in Fig. 4 - 10. In these figures one can see that the product formation begins immediately after the matrix separating the reactor sections, consisting of a full spectrum of the final reaction products.

From the data on consumption of the reactants pentane and oxygen, the highest rate of consumption is observed in front of luminous flame zone, and their concentrations remain practically constant at its inlet. Nitrogen concentration almost has no changes along the reactor axis. 
Curves describing changes of concentrations of ethylacetate, pentene and di-isopropyl ether are presented in Fig. 4. It is seen that the formation of pentene begins on the reactor matrix, and the maximum of its concentration is attained at a distance of $3.3-3.7 \mathrm{~mm}$ from the matrix, then the concentration falls to a certain value and remains then constant up to the end of reactor. The concentration profiles of ethyl acetate and di-isopropyl ether show that their formation begins nearer to the luminous flame zone and ceases in the flame front.

Fig. 5 demonstrates concentration curves of carbon dioxide, ethanol and benzene. All of these curves show that the formation of reaction products takes place in the preflame region. Slight amounts of carbon dioxide and ethanol are observed on the reactor matrix. Benzene formation is observed at a distance of $2 \mathrm{~mm}$ from the reactor matrix. These curves have their maximum in the front of the luminous zone of flame front. The ethanol concentration continues to increase through the combustion zone. The formation of small amounts of benzene is probably responsible for the resin formation observed at the reactor outlet.

Among the products of cool flame oxidation of iso-pentane, we have identified the following substances such as nitrogen, oxygen, hydrogen, carbon oxide, carbon dioxide, methane, ethylene, ethane, propylene, propane, water, iso-butane, methyl alcohol, formaldehyde, iso-pentane, ethanol, acetone, iso-propanol, ethylacetate, iso-butanol, pentanol-2, pentanol-1. One peak and several trace components have not been identified.

Profiles of methane, iso-butane, iso-propanol and iso-butanol concentrations are shown in Fig. 6. The methane and iso-butane concentrations reach maximum values in the luminous zone in the flame, while concentration profiles of iso-butanol and iso-propanol increase through the flame. 
Concentrations of iso-pentanol, formaldehyde and acetone are presented in fig. 7. The highest rate of acetone formation is observed in the region of the outside boundary of the front flame and acetone appears at a distance of $2 \mathrm{~cm}$ from the reactor matrix. Formaldehyde formation begins at a distance of $4 \mathrm{~cm}$ and reaches a maximum at the end of luminous flame zone. Iso-pentanol has a maximum at $7 \mathrm{~cm}$ from matrix and then is stable.

Among the products of cool flame oxidation of mixtures of n-pentane and iso-pentane we have identified nitrogen, oxygen, hydrogen, carbon oxide, methane, carbon dioxide, ethylene, ethane, propylene, water, methyl alcohol, acetaldehyde, ethanol, formaldehyde, acetone, methylacetate, iso-propanol, ethylacetate, iso-butanol, iso-pentanol, pentanol-1, toluol, iso-pentane, pentane. Several trace components have not been identified.

Curves describing formation of ethane, pentanol and methylacetate are presented in fig. 8. Pentanol formation is observed on the matrix burning and the essential increase of its concentration is observed after the flame region. Curves of ethane and methylacetate formation are passing through maxima in the upper boundary of the flame.

The concentration changes of propylene, acetone and ethylene are presented in fig. 9. It is shown that all the curves are passing through the maximums mainly located closely to the back luminous flame zone, and the highest concentration belongs to propylene.

Fig. 10 demonstrates the profiles of concentrations of acetaldehyde, formaldehyde and ethylacetate. The formation of these compounds is observed on the burning matrix. The concentration of formaldehyde increases constantly in the reaction products and then is stable. Acetaldehyde peaks $9 \mathrm{~cm}$ from the combustion zone from the matrix. The concentration of ethylacetate begins in the matrix and peaks before the luminous zone. 
For all three flames, the material balances of $\mathrm{C}, \mathrm{H}, \mathrm{O}$ and $\mathrm{N}$ were calculated. As an example, Table 2 presents data obtained from the calculation of material balance and changes of the coefficient of volume expansion in the isopentane-air cool flame. The coefficient of volume expansion is presented graphically in Fig. 11. Fig. 11 shows that the coefficient gradually increases and after $6 \mathrm{~cm}$ comes to a plateau.

Table 2 shows that the material balances in carbon, hydrogen, oxygen and nitrogen are fully satisfactory. 
The material balances in the iso-pentane flame and volume expansion coefficients. Values indicate percent deviations from absolute conservation. Table 2

\begin{tabular}{|c|c|c|c|c|c|}
\hline $\mathrm{L}, \mathrm{mm}$ & $\mathrm{C}, \%$ & $\mathrm{H}, \%$ & $\mathrm{O}, \%$ & $\mathrm{~N}, \%$ & $\alpha$ \\
\hline 0 & 0,01 & 0,56 & $-34,53$ & 9,96 & 0,9893 \\
\hline 10 & 0,54 & 1,14 & $-44,78$ & 11,52 & 0,9879 \\
\hline 15 & $-0,10$ & 0,55 & $-28,28$ & 8,35 & 0,9882 \\
\hline 20 & 0,31 & 0,96 & $-16,58$ & 3,68 & 0,9950 \\
\hline 25 & 1,34 & 2,15 & $-10,52$ & $-1,09$ & 1,0050 \\
\hline 30 & 1,50 & 2,59 & $-2,16$ & $-4,17$ & 1,0113 \\
\hline 35 & 0,32 & 1,59 & $-4,21$ & $-0,35$ & 1,0089 \\
\hline 37,5 & 0,56 & 1,77 & $-5,87$ & $-0,48$ & 1,0132 \\
\hline 40 & $-0,73$ & 0,67 & 2,20 & 1,97 & 1,0116 \\
\hline 42,5 & $-0,23$ & 1,43 & $-1,76$ & 0,30 & 1,0141 \\
\hline 45 & 1,23 & $-1,34$ & $-0,72$ & 1,24 & 1,0209 \\
\hline 47,5 & 0,07 & 1,93 & $-2,85$ & $-0,30$ & 1,0191 \\
\hline 50 & $-1,18$ & 0,86 & $-2,70$ & 3,07 & 1,0041 \\
\hline 55 & $-0,05$ & 2,03 & 1,54 & $-1,39$ & 1,0208 \\
\hline 60 & 0,39 & 2,56 & 2,70 & $-3,03$ & 1,0223 \\
\hline 70 & 0,92 & 3,28 & 8,35 & $-6,30$ & 1,0703 \\
\hline 80 & 1,14 & 3,99 & $-6,44$ & $-6,56$ & 1,0383 \\
\hline 90 & 0,69 & 3,61 & 2,38 & $-4,16$ & 1,0297 \\
\hline 100 & 1,51 & 4,49 & 4,87 & $-7,19$ & 1,0431 \\
\hline
\end{tabular}

\section{CONCLUSIONS}

In this study, experiments were carried out to provide a consistent database of species concentrations through low temperature flames of n-pentane, iso-pentane and their mixtures.

This data will be very valuable for future kinetic modeling studies to investigate the role of fuel molecular structure in cool flame oxidation of hydrocarbons. The kinetic information determined in this way will assist in refining kinetic models that describe such practical problems as engine knock, diesel fuel ignition and others such as homogeneous charge compression ignition (HCCI). 


\section{ACKNOWLEDGMENTS}

This work was performed under the auspices of the U.S. Department of Energy by the University of California, Lawrence Livermore National Laboratory under Contract No. W-7405-Eng-48.

\section{REFERENCES}

1. Westbrook C.K. and Dryer F.L. Chemical kinetic modeling of hydrocarbon combustion. Prog. Ener. Combust. Sci. 1984.10.1

2. Lignola P.G.,Reverchon E. Cool Flames Prog. Ener. Combust. Sci. 1987. V.13 .

3. Mansurov Z.A et al. Radical concentration and temperature oscillations in the butane cool flame oxidation. React. Kinetics and Catal. Lett.1990,v41, N2,p 265-270.

4. Mansurov Z.A et al. Defection of peroxy radicals and hydrogen atoms in hexane-air cool flames. In Flame structure. Novosibirsk, Nauka. 1991.v.1, p 89-92.

5. Mansurov Z.A., Bodikov D.U. Tracing of peroxy radicals in hexane cool flames. Reach. Kinet. Catal. Lett.- 1988, v 37, N1, p 31-35.

6. Westbrook, C. K., Pitz, W. J., and Leppard, W. M., Society of Automotive Engineers paper SAE 912314, 1991.

7. Curran, H. J., Gaffuri, P., Pitz, W. J., Westbrook, C. K., and Leppard, W. R.

"Autoignition Chemistry In A Motored Engine: An Experimental And Kinetic Modeling Study," Twenty-Sixth Symposium (International) on Combustion, pp. 2669-2677, The Combustion Institute, Pittsburgh, 1996.

8. Mantashjan A.A., Gukasjan P.S. DAN USSR. 1977, V.234, p.379

9. Azatjan V.V. at all. DAN USSR. 1975, V.224, N 4, p.841

10. Wigdergauz A.A. Gas cromatography. M .Chimia 1989 
Fig. 1. Scheme of the installation (explanation in text)

Fig. 2. Temperature profiles of pentane - air cool flame (1) and cool two- stage flame (2)

Fig. 3. Temperature profiles of iso-pentane - air cool flame (1) and pentane iso-pentane - air cool flame (2)

Fig. 4. Concentration profiles of ethylacetate (1), pentene (2) and di-isopropyl ether (3) in pentane - air cool flame.

Fig. 5. Concentration profiles of carbon dioxide (1), ethanol (2) and benzole (3) in pentane - air cool flame.

Fig.6. Concentration profiles of iso-butanol (1), methane (2) iso-propanol (3) and iso-butane (4) in iso-pentane - air cool flame.

Fig.7. Concentration profiles of iso-pentanol (1), acetone (2) and formaldehyde (3) in iso-pentane - air cool flame.

Fig. 8. Concentration profiles of ethane (1), pentanol (2) and methylacetate (3) in pentane - iso-pentane - air cool flame.

Fig. 9. Concentration profiles of propylene (1), acetone (2) and ethylene (3) in pentane - iso-pentane - air cool flame.

Fig. 10. Concentration profiles of acetaldehyde (1), formaldehyde (2) and ethylacetate (3) in pentane - iso-pentane - air cool flame.

Fig.11. The change of the coefficient of volume expansion in iso-pentane-air cool flame. 


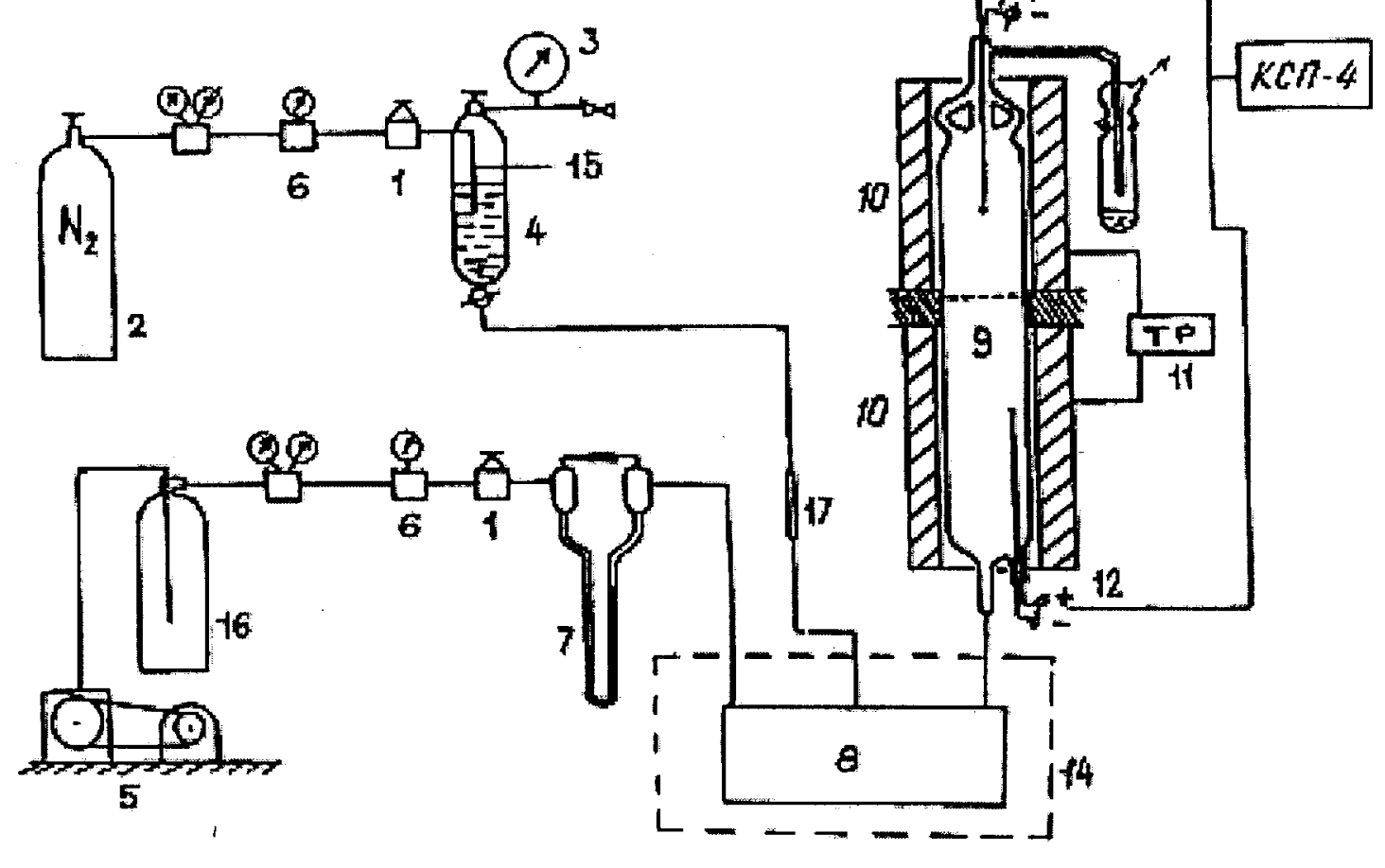

Fig. 1. 


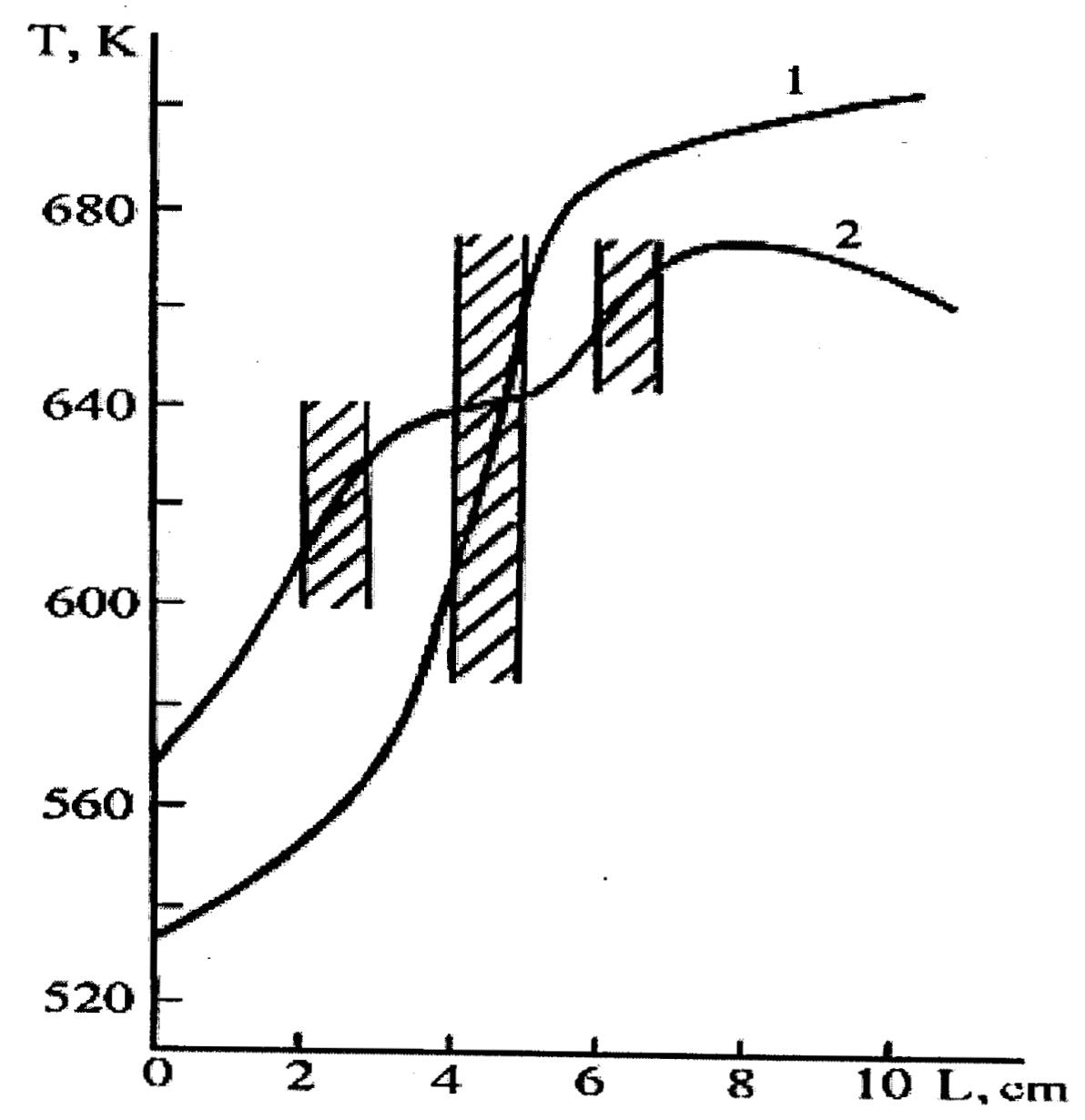

Fig. 2. 


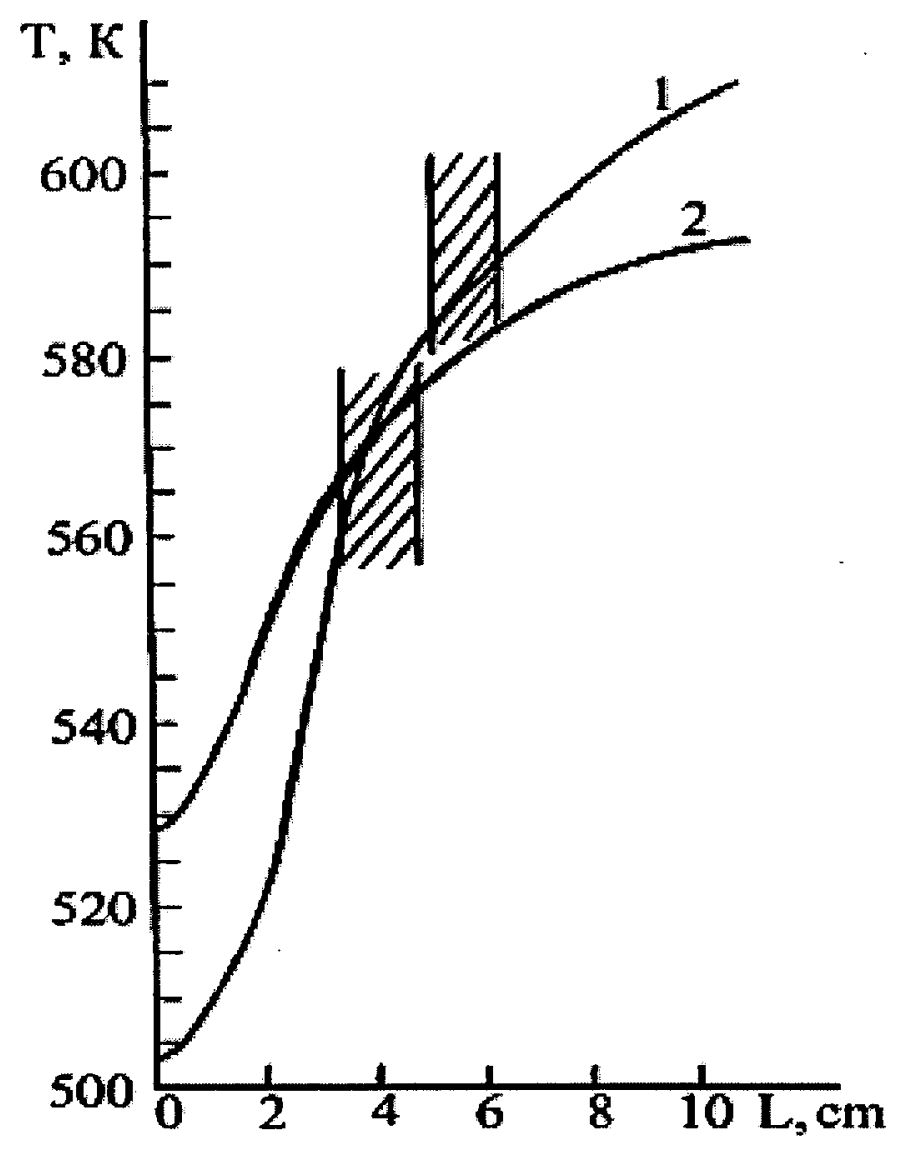

Fig. 3. 


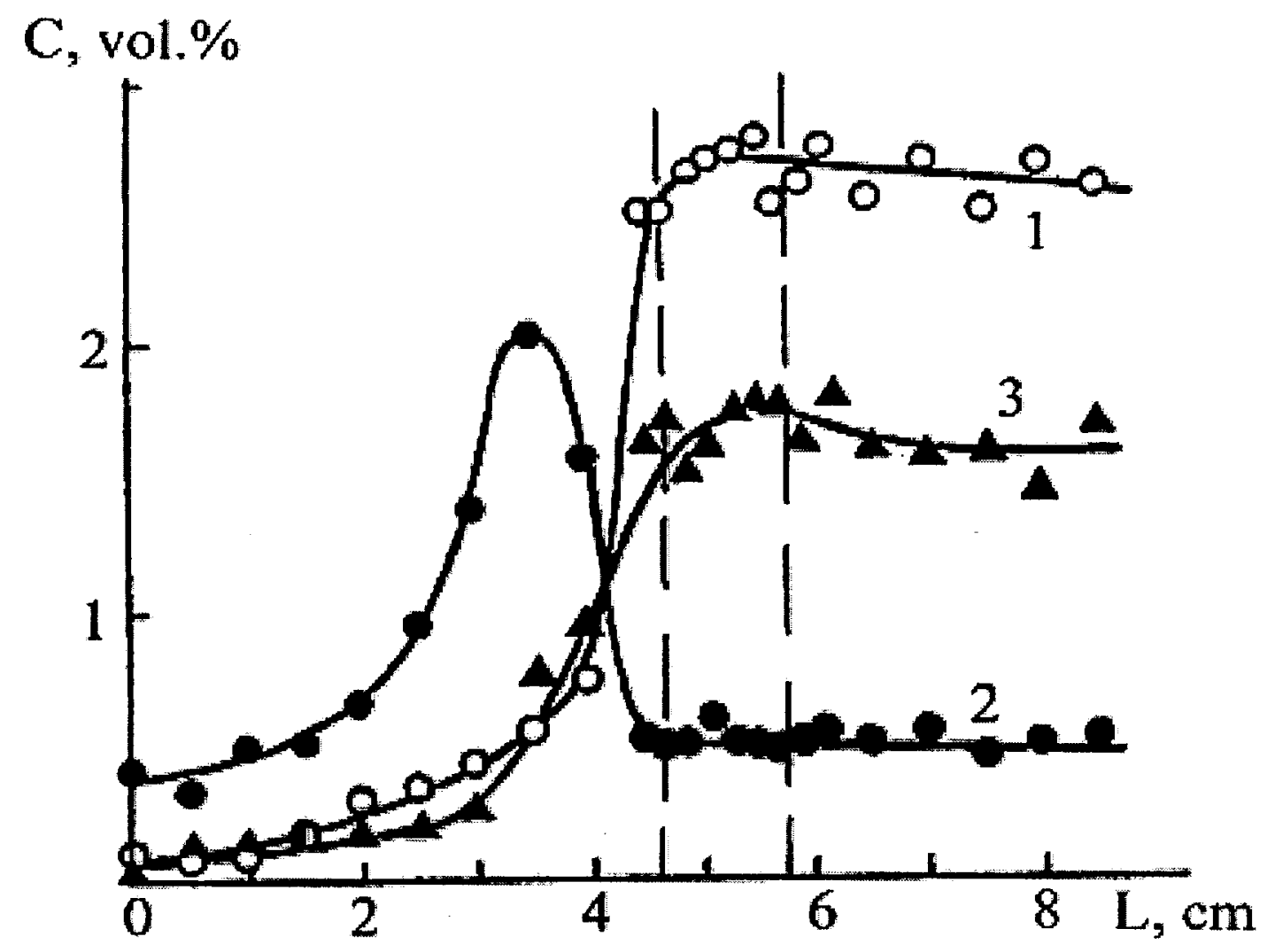

Fig. 4. 


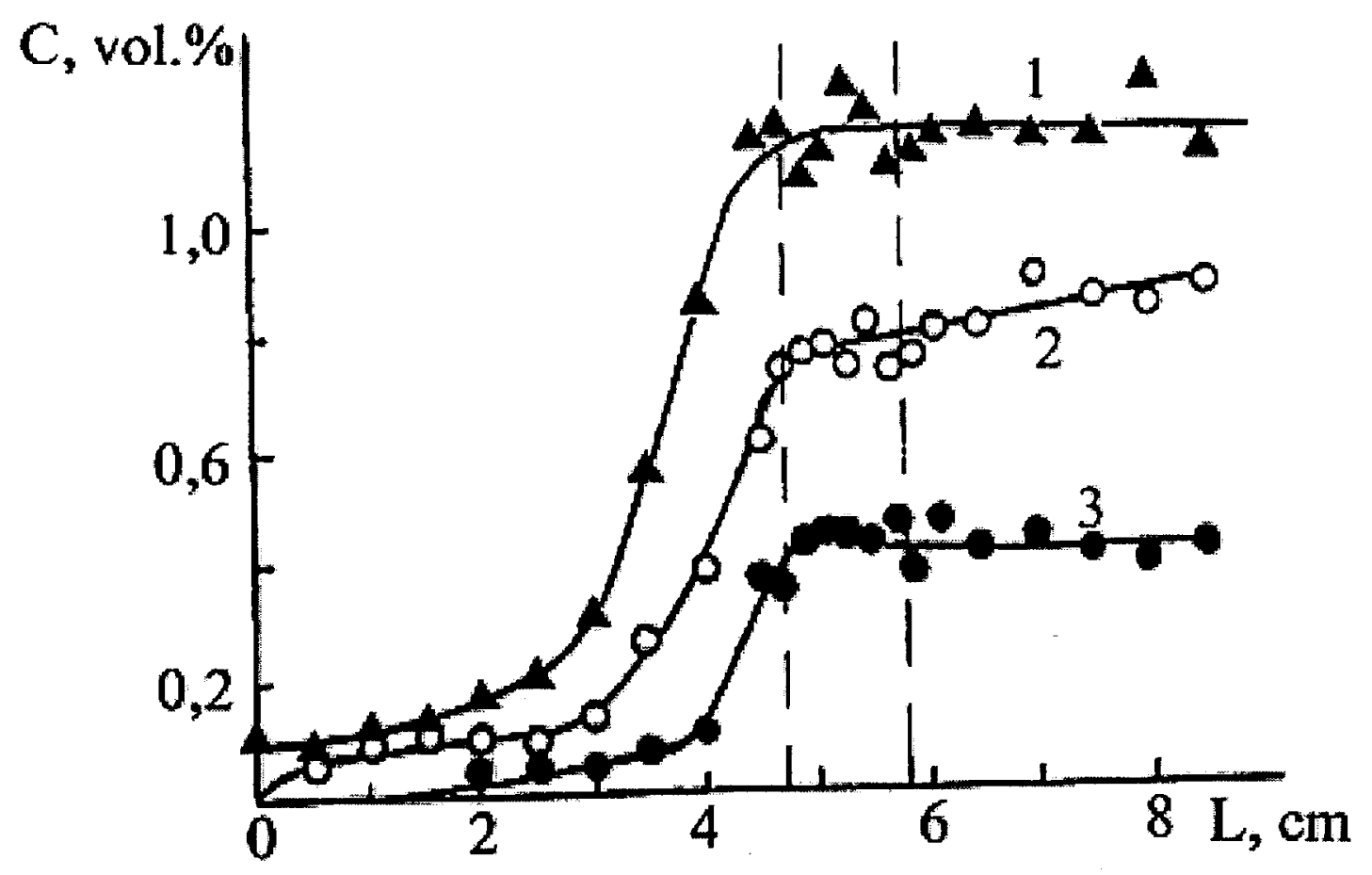

Fig. 5. 


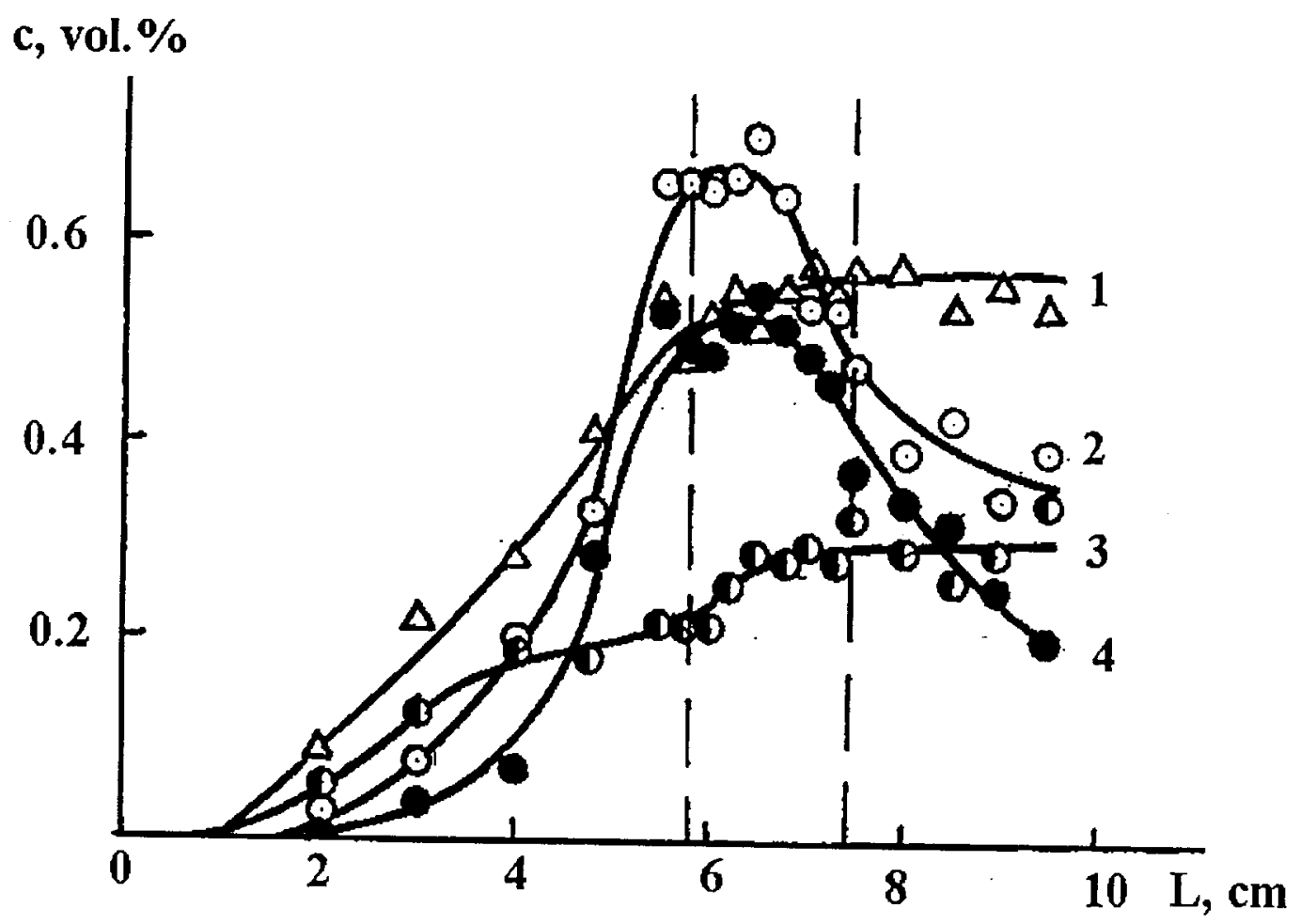

Fig. 6. 


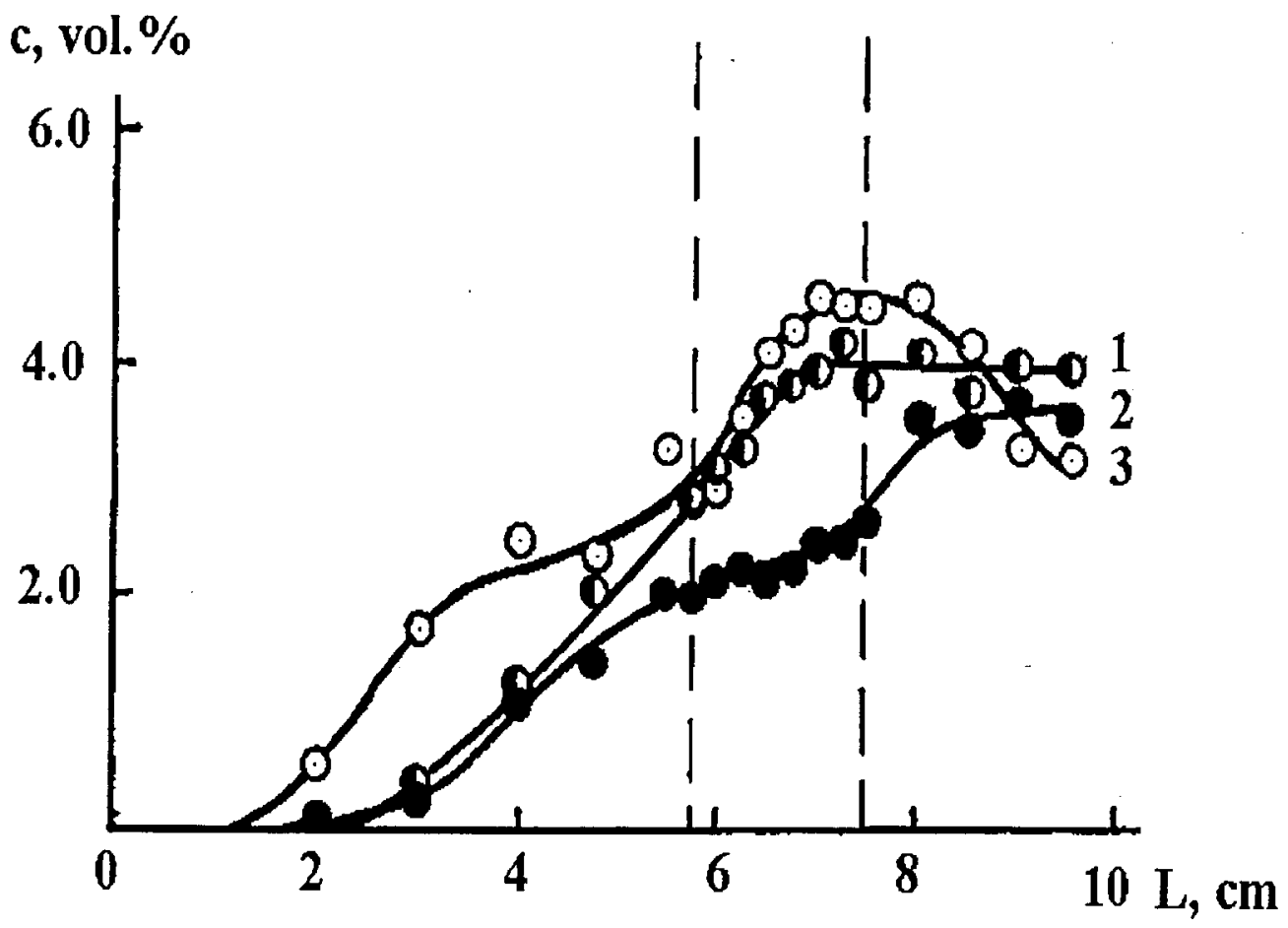

Fig. 7. 


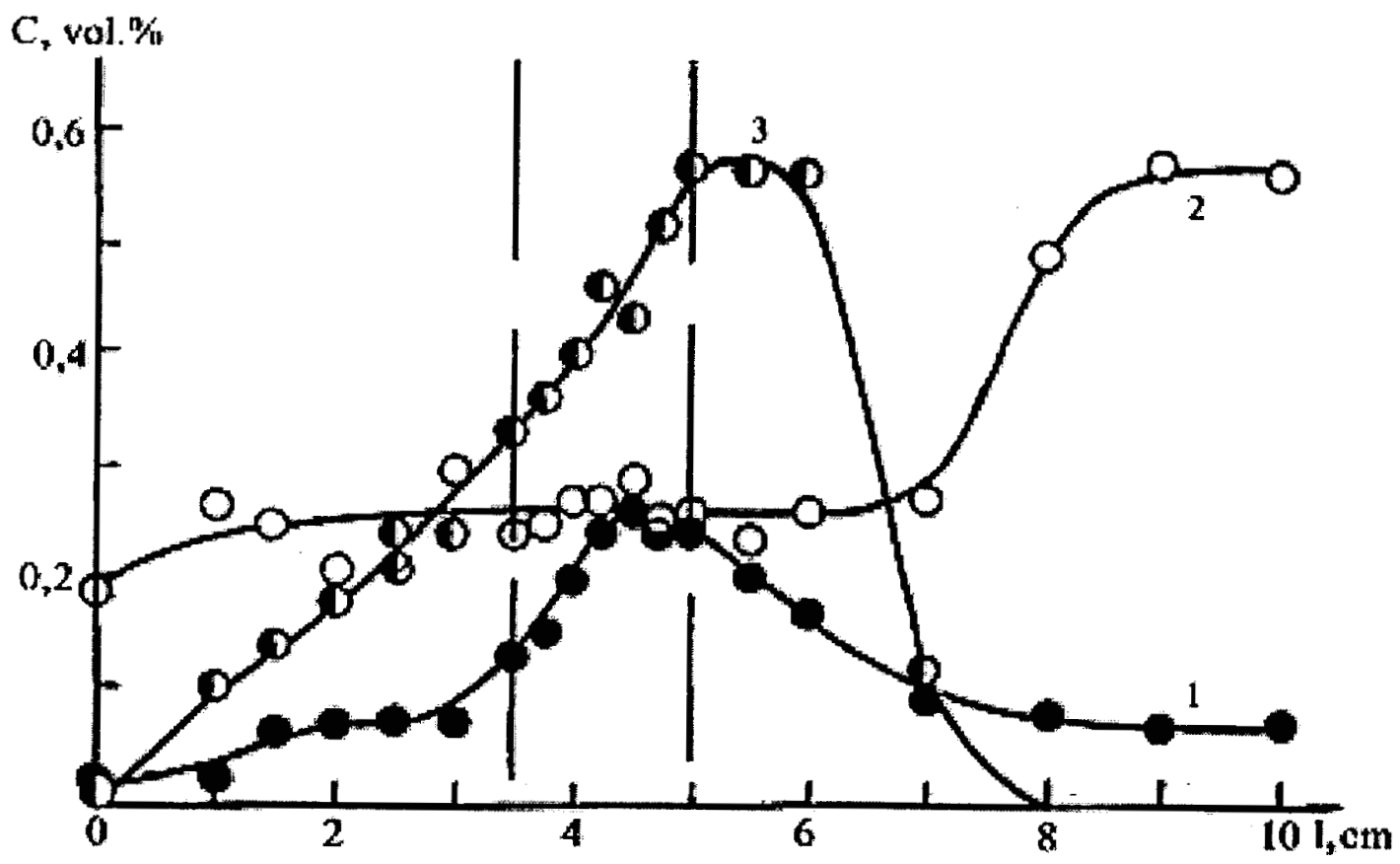

Fig. 8. 


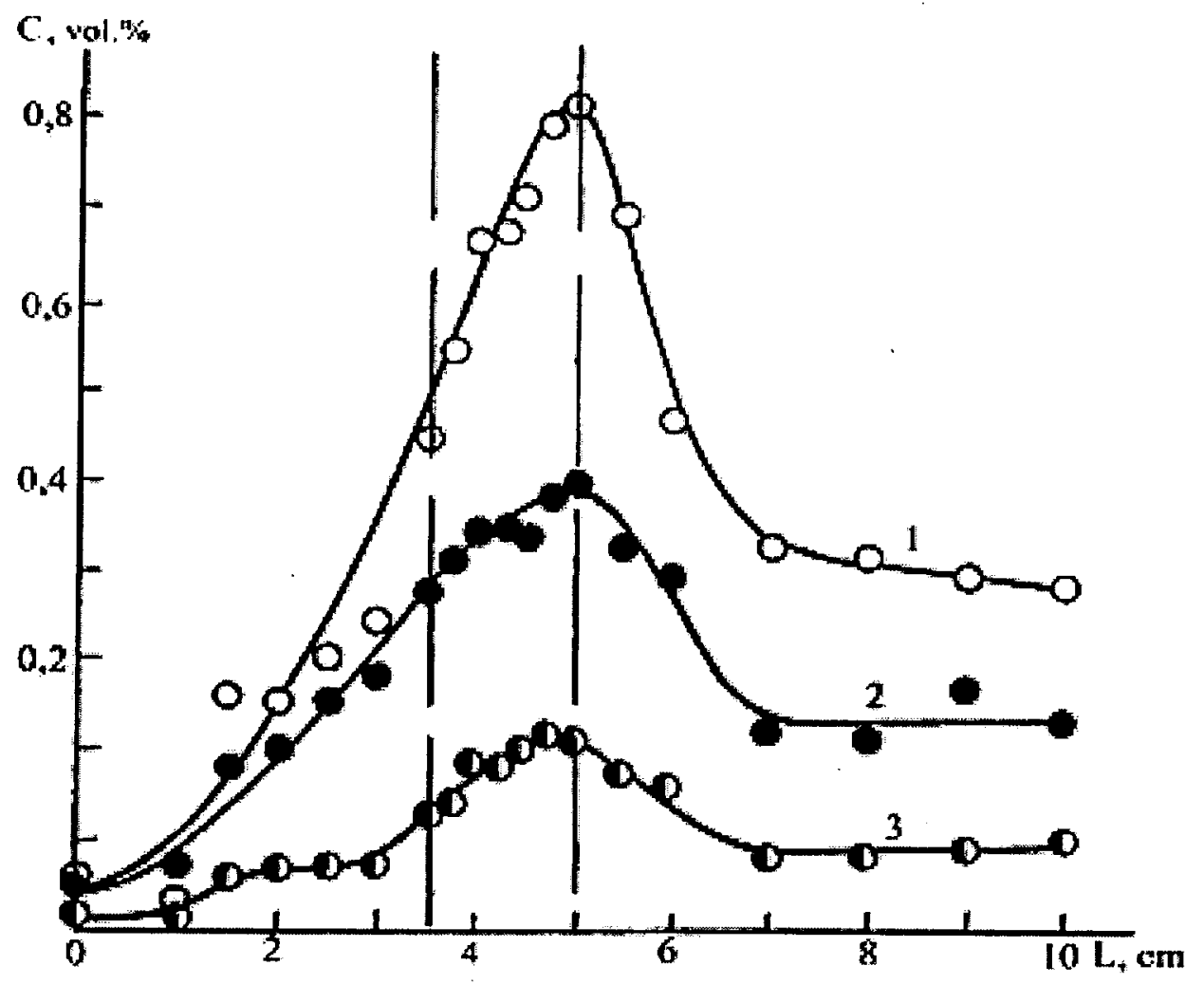

Fig. 9. 


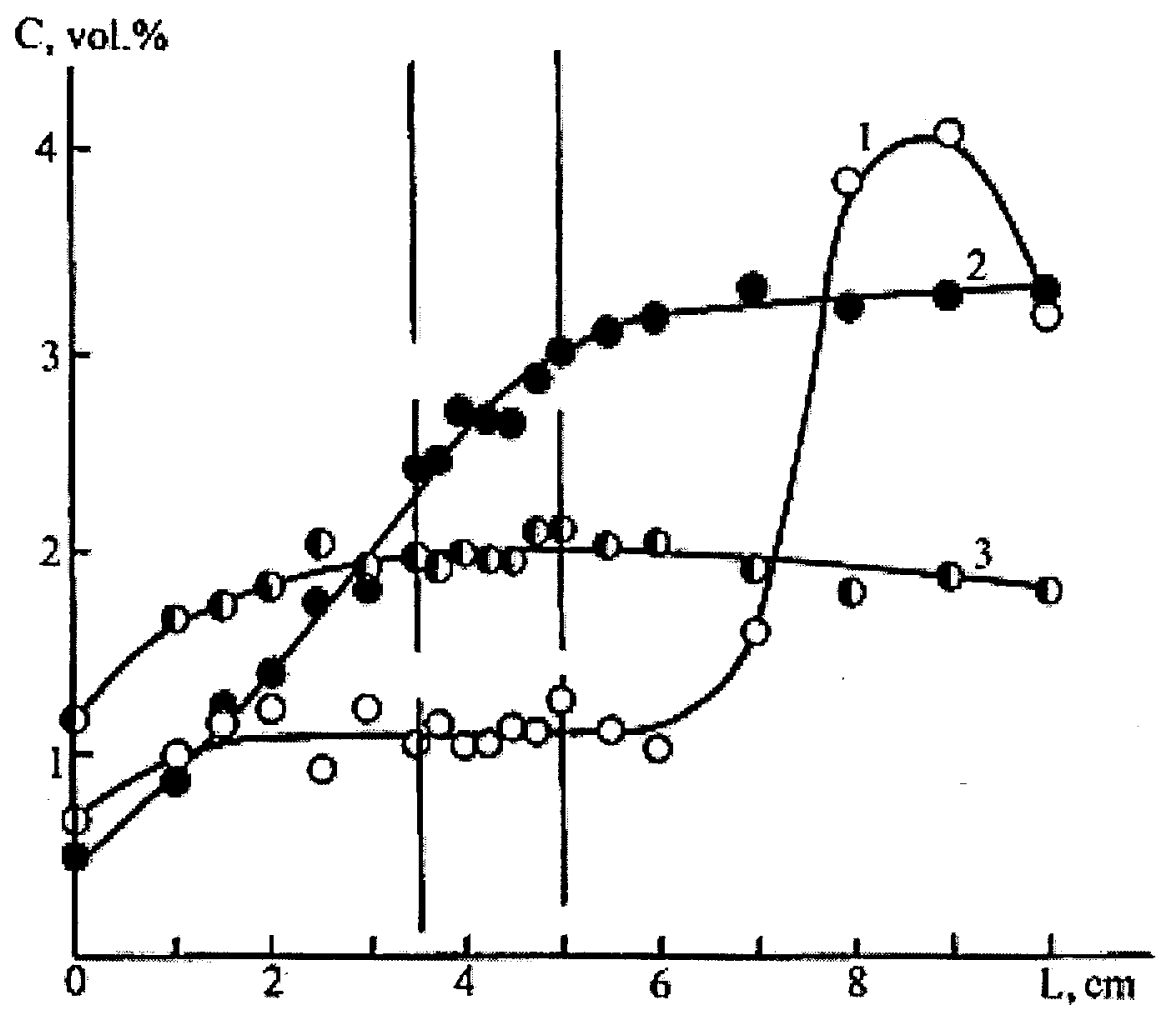

Fig. 10 . 


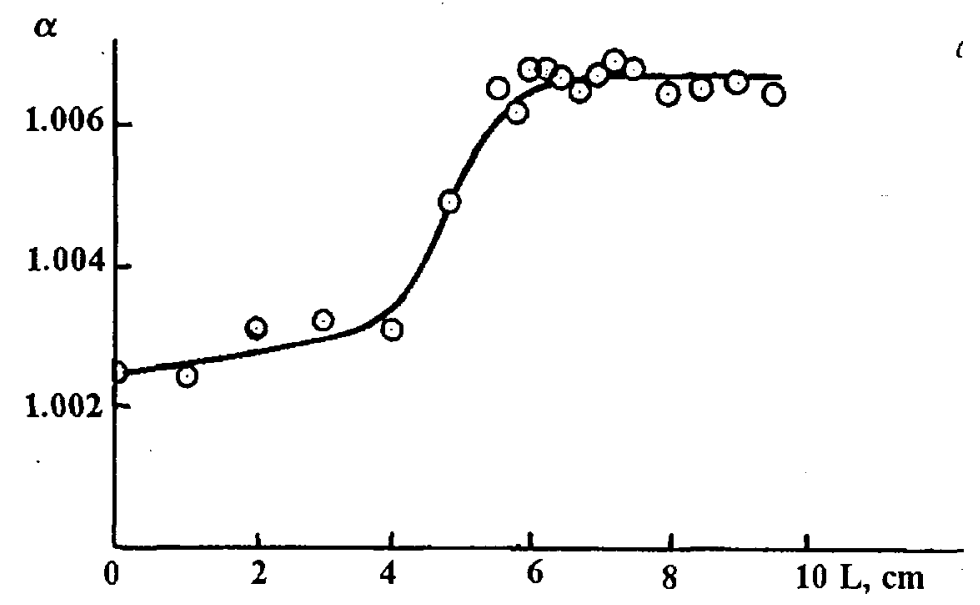

Fig. 11. 